BENM 2021

International Scientific and Practical Conference "Biotechnology, Ecology, Nature Management"

\title{
BIOINDICATION OF THE STATE OF THE LOSINY OSTROV FOREST
}

\author{
Natalya A. Mishakova (a)*, Zinaida S. Ruchkina (b), A. A. Nagiev (c) \\ *Corresponding author
}

(a) Institute of Biotechnologies and Fisheries, K.G. Razumovsky Moscow State University of Technologies and Management (the First Cossack University), Moscow, Russia, yfnbrcegth@mail.ru

(b) Institute of Biotechnologies and Fisheries, K.G. Razumovsky Moscow State University of Technologies and Management (the First Cossack University), Moscow, Russia, zinaidaru17@yandex.ru

(c) Department of State Environmental Supervision of Moscow and

Moscow region, Russia, aydyn.nagiyev@mail.ru

\begin{abstract}
The article deals with the ecological state of the forest area of Losiny Ostrov and the surrounding area. Methods of soil biotesting and bioindication of atmospheric air quality, conducted to study the state of forest and urbanized environments, are described. We can say that the main factors of negative impact on the ecological state of ecosystems in the study area are the fascination with the car fleet of personal and public transport, leading to huge emissions of exhaust gases, obstruction of movement and alienation of ever large natural landscapes for new highways and bypass roads, and also contamination of the soil cover with technical fluids of various nature. Ecosystem pollution problems must be considered from a prognostic point of view. And the fact that at this stage the results are quite encouraging does not mean that this problem does not require further consideration, as well as an urgent solution. The dynamics of the annual increase in environmental pollution must be reversed as long as possible
\end{abstract}

2672-8575 @ 2022 Published by European Publisher.

Keywords: Bioindication, biotesting, Losiny Ostrov, nature reserve, protected area, test objects 


\section{Introduction}

Losiny Ostrov, whose territory is 12881 hectares, is classified by the IUCN as a protected area of federal significance of the II category - the National Natural Park. It is located $1 / 3$ of its area within the city of Moscow, which is why a high technogenic load is imposed on the district, in particular, near the studied forest area there are Vostochny and Yantarny microdistricts, as well as the Shchitnikovo cottage village, the Vostochnaya waterworks continues its activity, attention requires a section of the Shchelkovo highway, which runs along the forest.

\section{Problem Statement}

The location of the national park within the city and close to major highways, industrial facilities, as well as its huge area does not allow equally effective control of the state of natural ecosystems.

\section{Research Questions}

The peculiarities of the location of the area chosen for the study suggest that due to the development of traffic flow and urbanization processes, oppression of phytocenoses occurs, caused by soil and atmospheric pollution, therefore it is important to assess the possibility of promptly detecting these problems by means of bioindication for their further solution (Grunina et al., 2019).

The study assumes the complex use of such methods as: methods of bioindication (phytoindication according to the condition of needles) and biotesting of the soil (on seeds of lettuce and radish).

Factors influencing the selected area of Losiny Island

It should be noted that there is a functioning waterworks on the territory of Vostochny, bearing the same name. In the village of Shchitnikovo, a dense development of private houses is underway, already now the approach to the forest is hampered by numerous fences and barriers. Also, the house requires household communications, but their quality is questionable, since numerous fires occur, for one of the reasons associated precisely with poor-quality wiring. The entire development raises questions about its legality and compliance with norms and standards (Gurkovskaya et al., 2019).

The situation with household waste is also deteriorating, returning us to the problem of littering. The main problem introduced by the section of the highway located near the object under study is exhaust gases and soil pollution with gasoline. Permanent traffic jams and numerous accidents characteristic of the study area only worsen with the growth of the population. Now the highway is partially relieved due to a change in the markings (previously the 6-lane highway, which converged into a 2-lane road, was reduced to 3-lane), but traffic is still difficult. To solve this problem, it is planned to build a bypass road that will pass through the Losiny Ostrov section. However, deforestation of a tangible strip of forest seems to many environmental scientists to be a bigger problem than a solution to the existing one (Gorbunov et al., 2020).

Bioindication (phytoindication), its advantages and disadvantages

An important section of bioindication is biotesting - a procedure for determining the toxicity of the environment using test objects that signal the presence of contaminants, regardless of their qualitative and 
quantitative composition. The obvious advantages of this method are the speed and cost of indication, however, it should be understood that these methods do not provide enough information about the causes and real concentrations of pollution, but provide information about the ability of the environment to provide organisms with the necessary resources, that is, data on the "viability" of the environment.

Phytoindication is now one of the most important areas of environmental monitoring, especially in urbanized ecosystems. Conifers are a widespread method of phytoindication of the ecological state of the atmosphere. Such plants react to pollution with various chlorosis and necrosis, and the age of the needles, which can reach 7 years, allows us to talk about pollution over a period of time. The main objects of indication in our strip are common spruce (Picea abies (L.) H. Karst., 1881), prickly spruce (Picea pungens Engelm.) And Scots pine (Pinus sylvestris L., 1753) (Ashikhmina, 2006).

Methodology for assessing air quality by the condition of the needles of Scots pine and Norway spruce / prickly spruce

The research methodology was taken from a textbook. For the study were allocated 4 zones. One zone with two points was selected in the forest part at different distances from the entrance to the forest and three zones in the urban area of the Vostochny microdistrict: near a house near a highway and a forest; on the main street, remote from the forest, and surrounded on both sides by a carriageway and at a house located in close proximity to the Vostochnaya waterworks.

Common spruce (Picea abies (L.) H. Karst., 1881) and prickly spruce (Picea pungens Engelm.) Were selected as the objects of indication. The needles collected according to the methodology specified in the manual were subsequently divided into groups according to the drying class and the presence / absence of necrotic and chloroetic spots, the results are entered in the table and processed.

Based on the results obtained (Table 1), we can talk about the average air pollution in the studied area. At the same time, samples of needles taken near the waterworks showed the lowest concentration of damaged needles, which indicates the absence or minimal damage to the atmosphere caused by the Vostochnaya station.

The opposite results were demonstrated by samples of spruce needles located on the site, surrounded on both sides by the roadway. Although the roads do not have heavy traffic during the day, the total number of all needle damage was $80 \%$, which is the highest figure. The needles had multiple necrosis and browning of the tips, in the lower part there were many branches devoid of needles in principle. This effect is exerted by vehicle exhaust, including ethylene. It should be noted that samples of needles taken in the forest showed $51.3 \%$ of the needles being damaged.

Table 1. Indicators of needles at various points

\begin{tabular}{|c|c|c|c|c|c|c|c|c|c|}
\hline $\begin{array}{c}\text { Characteristics of lesions } \\
\text { and drying out of } \\
\text { needles }\end{array}$ & $\begin{array}{l}\text { Plot } \\
\text { №1 }\end{array}$ & $\%$ & $\begin{array}{l}\text { Plot } \\
\text { №2 }\end{array}$ & $\%$ & $\begin{array}{l}\text { Plot } \\
\text { №3 }\end{array}$ & $\%$ & $\begin{array}{l}\text { Plot } \\
\text { №4 }\end{array}$ & $\%$ & $\begin{array}{c}\text { The } \\
\text { whole } \\
\text { area }\end{array}$ \\
\hline $\begin{array}{c}\text { The total number of } \\
\text { needles examined }\end{array}$ & 300 & 100 & 300 & 100 & 300 & 100 & 300 & 100 & $\begin{array}{c}12000 \\
(100 \%)\end{array}$ \\
\hline Number of intact needles & 156 & 49 & 59 & 20 & 150 & 50 & 160 & 53 & $\begin{array}{c}525 \\
(44 \%)\end{array}$ \\
\hline $\begin{array}{c}\text { Number of needles with } \\
\text { spots }\end{array}$ & 151 & 50,3 & 194 & 65 & 132 & 44 & 135 & 45 & $\begin{array}{c}612 \\
(51 \%)\end{array}$ \\
\hline The number of needles & 0 & 0 & 0 & 0 & 5 & 1,6 & 2 & 0,6 & 7 \\
\hline
\end{tabular}


tip)

\begin{tabular}{cccccccccc}
$\begin{array}{c}\text { Number of needles with } \\
\text { desiccation (all needles) } \\
\text { Damage and shrinkage }\end{array}$ & 3 & 1 & 47 & 15 & 13 & 24 & 1 & 0,3 & $\begin{array}{c}64 \\
(5 \%)\end{array}$ \\
\begin{tabular}{c} 
in general \\
\hline
\end{tabular} & 154 & 51,3 & 241 & 80 & 150 & 50 & 138 & 45,9 & $\begin{array}{c}683 \\
(57 \%)\end{array}$ \\
\hline
\end{tabular}

This phenomenon can be explained by exhaust gases from the section of the Shchelkovskoye Highway and the Moscow Ring Road, which can be carried by air streams at different distances. Also, samples were taken from spruce trees located near the walking path, which allows a direct negative impact of humans on trees. Separately, it is worth noting the non-single prints of car wheels on the ground near the sampling site, although the movement of personal vehicles in the national parks is limited or prohibited (Veklenko et al., 2019).

Since samples taken at points with different levels of urbanization showed different results from each other, we can say that this indication method is applicable both in urban conditions and in forest and forest-park zones. In the course of the study, in practice, it was confirmed that phytoindication according to the condition of needles can be carried out in winter, unlike most other bioindication methods, which are relevant only in warm weather.

Method of biotesting soil samples for germination of radish and leaf lettuce seeds as test objects.

For a complete picture of the ecological state of the study area, soil biotesting was carried out in parallel. The research methodology was taken from a textbook. In the study, soil samples were taken at 5 points. (Figure 1): at a house located at a small distance from the forest and a section of the Shchelkovskoye highway; at two points in the forest at different distances from the entrance and the highway, respectively; at the bus stop in Vostochny; at the bus stop near the Shchelkovskoye highway. River sand and purchased land with the following composition were selected as control samples: total $\mathrm{N}$ not less than $75 \mathrm{mg} / \mathrm{l}$, P2O5 not less than $150 \mathrm{mg} / 1$, K2O not less than $200 \mathrm{mg} / 1$, Mg not less than 75 $\mathrm{mg} / \mathrm{l}$, and the following trace elements (mg / kg): Fe - 0.8-0.2; $\mathrm{Zn} \mathrm{0.2-3;} \mathrm{Cu} \mathrm{-} \mathrm{3-5;} \mathrm{Mn} \mathrm{8-40;} \mathrm{Mo} \mathrm{-} \mathrm{0.1-}$ $0.4 ; \mathrm{B}-0.4-1.6 ; \mathrm{pH}-5.5-6.5$.

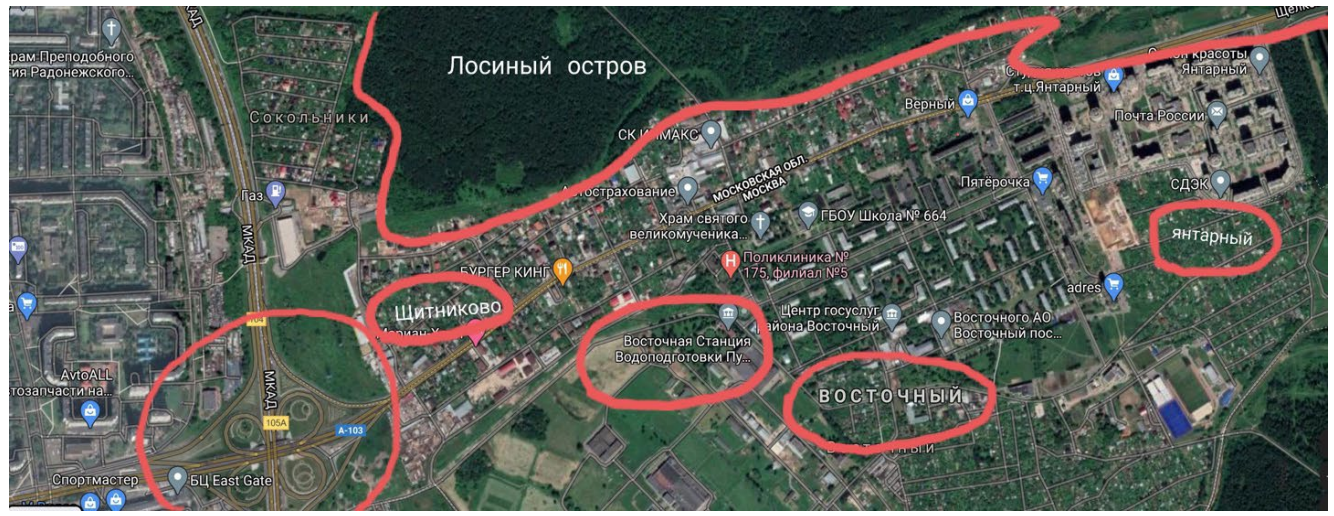

Figure 1. Sampling areas

The results were taken on a daily basis. The results of measurements of the average size of the sprout and root in the sample, the percentage and average percentage of germination, the energy of 
germination and the germination of seeds were entered in the table, according to the data of the table, an analysis was carried out and the corresponding conclusions were drawn.

According to the results of the study, in all samples, except for the sample taken from the roadside, high (above 90\%) indicators of average germination, and the germination energy and germination rate do not fall below $70 \%$. Good results in two of the three samples were obtained from samples taken at a short distance from the entrance to the forest, comparable to the results of the control sample and high-humus peat soil purchased from the store. This indicates a high resistance to anthropogenic interference by natural ecosystems. However, soil samples taken near the trail, but at a sufficient distance from the entrance to the forest, showed significantly lower results in three samples. This may be due to the direct impact of humans, formed when entering the forest, garbage dumps left by residents of the adjacent cottage village and people who come to the forest for walks.

A visual inspection revealed many canisters of engine oil and other technical fluids, as well as small household waste. It is important that this method should be used at freezing temperatures or until the soil is frozen and covered with a thick cap of snow. In other circumstances, sampling will be difficult. It is worth noting that the sprouts and seeds of radish are much larger than those of lettuce, which is more convenient when measuring, but in almost all soil samples, radish seeds germinated in the same way, based on which, one can say about the low sensitivity of radish to pollution. This means that when testing, you should give preference to lettuce seeds (Glebova et al., 2019).

The study showed that the seeds of both types of test plants germinate worst of all on soil samples taken on the side of the Shchelkovskoye highway. During the entire study period, none of the seeds started germination, although the irrigation and lighting conditions were identical. This can be explained by the impact of vehicles on this area. This is confirmed by the results of the analysis of needles, which showed an extremely detrimental effect of automobile emissions on coniferous phytocenoses and ecosystems in general.

\section{Purpose of the Study}

The aim of this work is to identify atmospheric and soil contamination of the Losiny Ostrov forest area and the developing urbanized area adjacent to it by bioindication methods.

\section{Research Methods}

Soil samples were distributed in containers, each sample was taken 3 times. Soil samples are actively moistened; in this study, tap water was used, purified by the Aquaphor A6 household filter with replaceable modules, which is a charcoal filter. Next, a cloth napkin was lined for the sample, which absorbed the extract from the ground, and the seeds of radish and lettuce were laid on it in two halves, without mixing (10 pieces of each type).

There was a daily difference between the first and subsequent samples. Further, the seeds are exposed in a well-lit place, since daylight hours in winter are shortened for an objective assessment of germination, additional lighting is required. For this study, an LED lamp was chosen, which was turned on during the evening and morning periods when there was not enough light. To preserve moisture, the 
plants were covered with a thin cloth at night. The seeds were watered every day or every other day, depending on the moisture of the soil.

\section{Findings}

A visual inspection revealed many canisters of engine oil and other technical fluids, as well as small household waste. It is important that this method should be used at freezing temperatures or until the soil is frozen and covered with a thick cap of snow. In other circumstances, sampling will be difficult. It is worth noting that the sprouts and seeds of radish are much larger than those of lettuce, which is more convenient when measuring, but in almost all soil samples, radish seeds germinated in the same way, based on which, one can say about the low sensitivity of radish to pollution. This means that when testing, you should give preference to lettuce seeds.

The study showed that the seeds of both types of test plants germinate worst of all on soil samples taken on the side of the Shchelkovskoye highway. During the entire study period, none of the seeds started germination, although the irrigation and lighting conditions were identical. This can be explained by the impact of vehicles on this area. This is confirmed by the results of the analysis of needles, which showed an extremely detrimental effect of automobile emissions on coniferous phytocenoses and ecosystems in general..

\section{Conclusion}

Summing up, we can say that the main factors of negative impact on the ecological state of ecosystems in the study area are the fascination with the car fleet of personal and public transport, leading to huge emissions of exhaust gases, obstruction of movement and alienation of ever large natural landscapes for new highways and bypass roads, and also contamination of the soil cover with technical fluids of various nature.

Ecosystem pollution problems must be considered from a prognostic point of view. And the fact that at this stage the results are quite encouraging does not mean that this problem does not require further consideration, as well as an urgent solution. The dynamics of the annual increase in environmental pollution must be reversed as long as possible.

\section{References}

Ashikhmina, T. Y. (2006). School environmental monitoring. Academic Project.

Glebova, I. A., Veklenko, V. I., Ponomarev, A. K., Nozdracheva, H. N., \& Serebrovskei, V. E. (2019). The effectiveness of tools for protecting the environment from immiscible pollution. Vestnik Kurskoy gosudarstvennoy sel'skokhozyaystvennoy akademii, 3, 167-173.

Gorbunov, A. V., Nikiforov-Nikishin, D. L., \& Gorbunov, O. V. (2020). Problems of optimization of agricultural nature management, due to complex reclamation measures. Vestnik Kurskoy gosudarstvennoy sel'skokhozyaystvennoy akademii, 5, 46-51.

Grunina, A. A., Glebova, I. A., Fedorov, S. I., Shatohin M. V., \& Klimov V. A. (2019). Comparative assessment of ecologically oriented land use in individual regions. Vestnik Kurskoy gosudarstvennoy sel'skokhozyaystvennoy akademii, 60-66. 
Gurkovskaya, E. A., Romanenko, A. I., Tarakanova V. V., Prancus O. S., Shatochin M. V., \& Golovacheva N. A. (2019). Quality about the environment and innovation in construction. Moscow State University of Technology and Management. K.G. Razumovsky (First Cossack University).

Veklenko, V. I., Nikiforov-Nikishin, D. L., Glebova, I. A., \& Duplina, T. T. (2019). Management and control instruments for combating environmental pollution. Vestnik Kurskoy gosudarstvennoy sel'skokhozyaystvennoy akademii, 1, 93-104. 